\title{
STUDENTS' QUESTIONS IN INQUIRY-BASED CHEMISTRY CLASSROOMS
}

\author{
Winnie Sim Siew Li ${ }^{1}$, Mohammad Yusof Arshad ${ }^{2}$. \\ Universiti Teknologi Malaysia \\ winniesim50@gmail.com \\ mohammadyusroarshad@gmail.com
}

\begin{abstract}
Questioning plays an important part in the teaching and learning science. Previous research has extensively focused on teachers' questions compared to students' questions. Research of students' questions is vital as it shows how students think and their understanding of a content studied. Hence, this research focuses on students' questions, types of questions asked and the sequence(s) after students' question. Twenty three chemistry teachers and their students of national secondary schools were involved in this study. Ninety two chemistry lessons were observed, audio and video recorded. Transcript of the lessons showed that students' questions were mainly related to content or science process skills as emphasised in inquiry teaching and learning. However, most questions asked by students were low order closed questions. The sequence after students' questions with the highest percentage (83.33\%) was IR (Initiation from student, followed by teachers' response). This sequence showed that chemistry teachers in this study did not display inquiry-based questioning characteristics because in inquiry teaching, teachers should avoid responding to students' questions. Instead, they should provide opportunities for students to respond to their friends' questions. Hence, teachers should move towards student initiated inquiry, where students ask higher order thinking questions and increasing the interaction among the students.
\end{abstract}

Keywords: Students' Questions, Questioning, Sequence, Inquiry-Based Teaching, Interaction

A teacher, a prominent figure in teaching and learning process, plays a vital role in a classroom. They should be able to implement teaching approaches as suggested in the curriculum. One of teaching approaches suggested in Malaysia's chemistry curriculum specification is inquiry approach (Curriculum Development Centre, 2005). In inquiry-based classroom, the utmost importance is the questions that students ask (Wells, 1995; Martin, et al., 2009; Howes, Lim and Campos, 2009). Through the process of questioning, students are able to build a deep understanding of a concept (Suchman, 1966; Tobin, 1990; Yahudit and Herscovitz, 1999; Hinrichsen and Jarrett, 1999; Campbell, Zhang and Neilson, 2011), science 
process skills and nature of science (Campbell, Zhang and Neilson, 2011) as they are actively involved in the learning process.

Typical classroom scenario showed that students rarely ask question as reported by Dillon (1988); Chin (2002); Blonder, Namlok-Naaman and Hofstein (2008). Not much researches were done on students' questions (van Zee et al, 2001) compared to teacher's questions. Chin and Osborne (2008) claimed that less attention was given to this aspect. Previous researches done on students' questions found that the percentage of students' questions was very low (Mohamed Najib and Mohammad Yusof, 1995; Jegede and Olajide, 1995; Tay and Mohammad Yusof, 2008). This scenario occurred due to the fact that students felt their questions were not appreciated, lack of encouragement by their teachers and they were not given sufficient time to think (Rop, 2003). However, Albergaria-Almedia (2010) found that students asked ample number of questions in chemistry classroom that they observed. Nevertheless, questions asked by the students were mainly not related to chemistry content. In Malaysia, there will be a revamp in the examination questions which focuses more on questions which requires higher order thinking questions to ensure that Malaysia's performance improved in the next TIMSS and PISA cycle as stated in Preliminary Report-Executive Summary National Education Blueprint 2013-2025 (Ministry of Education, 2012). Hence, it is of utmost importance to study students' questions to get an insight view of their thinking. There should be a difference in the type of questions asked by students in traditional and inquiry-based classroom. Thus, this study looks into the type of questions asked by students in inquiry-based chemistry classrooms.

As inquiry-based teaching is a student-centred approach (Kim, Tan and Talaue, 2013), students are expected to be active in the learning process. It means that students should be involved in the process of responding to questions asked by other student(s). Furthermore, students should be able to provide evidence in responding to questions as emphasised in National Science Education Standards (National Research Council, 2000).

Besides students' questions, there has been vast previous research done on teaching sequence (Sinclair and Coulthard, 1975; Mortimer and Scott, 2003). Most of the researches done found that the common teaching sequence was IRE (Initiation, Response, Evaluation). It means that a teacher asks a question, students give response, followed by evaluation by the teacher (Sinclair and Coulthard, 1975; Scott, Mortimer and Aguiar, 2006). This sequence is also known as triadic dialogue and was found in most classrooms in United States (Lemke, 1990; Kumpulainen and Wray, 2002). However, we would argue that the study of sequence after students' questions is of equal importance as sequence after teacher's questions. It reveals how students' questions are being responded. Inquiry-based classroom emphasises students' dialogue. Students' dialogue involves students asking questions, followed by their friends' responses and the process will continue until a full understanding of a concept of phenomena is obtained. Understanding the 
sequence(s) after students' questions is vital as it provides insights on the turn taking that occurs in classroom. Hence, if students were to ask question(s), what is/are the possible sequence(s) after students' questions? This aspect of sequence after students' questions is important to be analysed as we would see how teachers and students response towards students' questions. In this research, focus will be on the type of students' questions in inquiry-based classrooms and the sequence(s) of interaction that occurred after students' questions in chemistry classrooms.

\section{METHOD}

A total of twenty three chemistry secondary school teachers who practiced inquiry teaching were involved in this study. All of them were from thirteen different secondary schools and implement the same chemistry curriculum which was developed by Curriculum Development Centre, Ministry of Education, Malaysia (2005). Each teacher and their students were observed for four lessons. Duration of each lesson is 60 to 80 minutes. The chemistry lessons observed were video and audio recorded after obtaining consent from the respondents. A total of ninety two chemistry lessons were transcribed and analysed manually to determine the sequence after students' questions. The process of transcribing the video recorded and audio recorded chemistry lessons were done twice. The first process of transcribing is listening to the audio recorded lesson. Then, the second process is listening to the video recorded lesson. These two steps are taken to ensure the validity of the transcription. An observation instrument, known as Observation Instrument in Inquiry Teaching through Verbal Interaction (OIITVI) was used. This instrument was modified from previous existing classroom observation instruments (Flanders, 1970; Eggleston, Galton and Jones, 1976; Mohamed Najib, 1997; Brandon et al., 2008). It consists of five main categories of verbal interactions. The main categories are teacher's question, teacher's statement, student's question, student's statement and silence or confusion.

\section{RESULT AND DISCUSSION}

In this section, discussion will be based on types of students' questions and the sequence(s) of verbal interaction that occurred after students' question.

\section{Types of Students' Questions}

Overall, student's questions contributes $7.52 \%$ of the total verbal interaction that occured during chemistry lessons. In this study, there are two main categories of student's questions. The categories are questions related to content or science process skills and questions not related to content or science process skills. $75.07 \%$ of the students' questions were content or science process skills (see Figure 1). Questions that are not related to content or science process skills raised by the students were for classroom management purposes. Based on Figure 1, the ratio between the two main categories of students' questions are three to one. 
However, the result found from this study contradicts with research done by Albergaria-Almedia (2010) which stated that in a chemistry classroom, $75 \%$ of students' questions was not content-related.

\section{Not related to \\ Content science \\ Skill $2493 \%$}

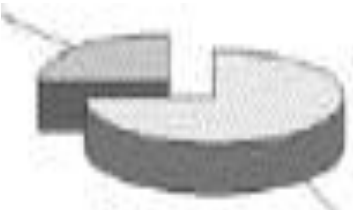

\section{Relate to}

Content science

\section{process skills $75,07 \%$}

Fipna-a 1 Categories of students questions

Next, the students' questions which are related to content or science process skills are further analysed. It was found that students raised questions to obtain information or confirm a fact, principle or concept, and to ask for clarification of a process (usually related to practical procedure or technique). Student's questions not related to content or science process skills are managerial questions. Further analysis of types of questions students asked, it was found that students' questions were mainly consists of closed-ended questions. A total of 3225 questions were asked by students. A total of 1616 questions (50.11\%) questions were closed-ended questions, followed by managerial questions, 1537 questions (47.66\%). Only 72 questions (2.23\%) represents open-ended questions (see Figure 2).

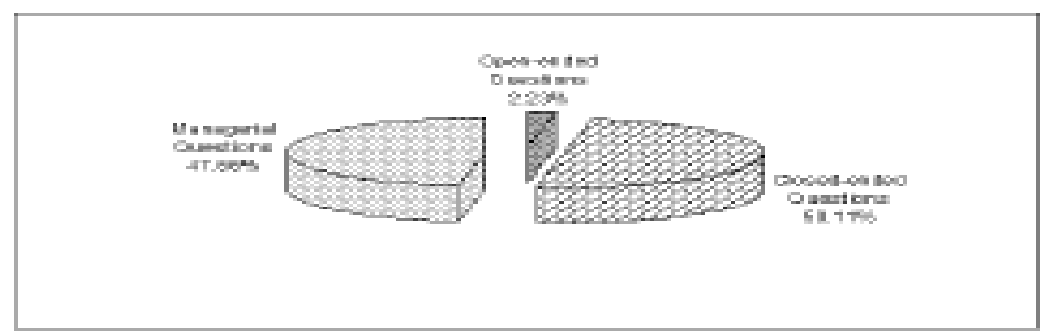

Figure 2 Catagarien of studants" quections

As mentioned in the previous paragraph, the types of students' questions were mainly closed-ended questions. These questions do not promote high order thinking skills. This study showed that the purpose of students asking questions 
were merely to get clarification and confirmation of certain facts. Example of students' questions related to content or science process skills are as follows:

Teacher, this thirty one ok? [confirmation]

Teacher... this one has to find the number of moles first? [confirmation]

How to record? [clarification]

Ideally, in an inquiry-based classroom, students' questions should be open-ended question type that could enhance students' thinking skills, and higher order level thinking questions. This type of question is encouraged in inquiry- based classroom (Lemke, 1990; Mortimer and Scott, 2003). Besides that, one of the characteristics of inquiry-based classroom is students ask scientifically oriented questions (National Research Council, 2000). However, this characteristic was not shown in this study.

\section{Sequence After Students' Question}

Based on the analysis done on 92 chemistry lessons observed, it was found that there are five types of sequences after students' questions (see Table 1).

The sequence after students' questions which recorded the highest percentage was IR $(83.33 \%)$. Sequence IR indicates that students' questions were followed by feedback from the teacher. This type of sequence showed that these students are likely to be dependent on their teachers to give feedback on questions asked. Hence, this does not encourage students to discuss with their friends on the content that is currently being discussed. This sequence is less likely to show inquiry characteristic. Example of transcribed lesson that showed this sequence is shown below.

\begin{tabular}{|c|c|c|c|}
\hline Iype & $3=-9=0000$ & Fromban=0 & Ifeurcentage $\mathrm{ma}$ \\
\hline 1 & IIE & 1570 & $3 \geq \geq 3$ \\
\hline$\geq$ & $\mathrm{IE}_{1}$ & $\geq \equiv 2$ & $1 \geq \pm 1$ \\
\hline$\exists$ & INIE & \pm 3 & 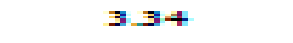 \\
\hline 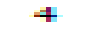 & IIEII & 13 & $0 \cos$ \\
\hline \multirow[t]{2}{*}{5} & Atthers & $E$ & 0103 \\
\hline & Ieter & $1 \pm \equiv-4$ & 10000 \\
\hline
\end{tabular}

S: Teacher, in displacement, higher metal loses or gain electron? [I]

T: Higher [R]

$\mathrm{S}$ : Is the higher referring to electrode? [I]

T: The electrolyte is the solution, right? Ok.so, we want to displace metal in the electrolyte. R]

S: So, the metal must be more electropositive? [I]

T: Correct. [R] 
[R16: Theory Class]

Next, the second highest percentage is IRp sequence (12.31\%). This sequence shows that other students answered their friends' questions. It shows that the teacher allows other students to respond, either by asking, giving comment or to give feedback to questions posed by their classmates. Eventually, students will be less dependent on the teacher to give feedback.

Below is an example of a transcribed lesson that showed IRp sequence.

S3 : Really brown? [I]

Milah : Looks like Milo powder S5 :

Ooh...

S3 : Eh...eh... Milah says looks like

MILO powder. Rp]

Milah : A bit darker.

S3 : MILO powder but a bit darker. .

[R2: Practical Class]

S3: Student 3, S4: Student 4, S5: Student 5; R2: Respondent 2

IRRp sequence is the third highest percentage (3.34\%). It shows that after students asked questions, the teacher responded and followed by other students giving feedback to the same question. This sequence shows that students might just agree with teachers' statement, and they might less likely to give their own opinion or view on a particular concept or phenomena discussed. The following transcript shows the above mentioned sequence.

S4: Why put that inside? [I]

T: For the heating purpose... [R]

S5: Yes... [Rp]

[R16: Theory Class]

S4: Student 4, S5: Student 5; T: Teacher; R16: Respondent 16 Apart from the above mentioned types of sequences, is type 4 sequence (IR3R), which constitutes $0.69 \%$. In this sequence, a student asks a question, and then the teacher asked the question to other students in the classroom. Finally, the teacher responds to the question he/she asked. In other words, the teacher does not wait for students to respond. This phenomenon is shown in part of the transcript below.

S1: Can we store reactive metals in water? [I]

T: Can or not? [R3]

$\mathrm{T}$ : Cannot, because it can react with.water. [R]

[R03: Practical Class] 


\section{S1: Student 1, T: Teacher, R03: Respondent 3}

The above sequence, (IR3R), showed the teacher did not practise wait-time in the classroom. Type 5 sequence which consists of several other sequences was not discussed in this article as this type of sequence contributed only $0.03 \%$ of the total percentage of other type of sequences. Based on the discussion above, only type 2 sequence (IRp) reflected inquiry teaching approach.

\section{CONCLUSION}

Results obtained from this study showed that although students ask questions in an inquiry-based classroom, the students' questions were mainly on asking clarification or getting confirmation of a certain concept or facts. Questions asked were mainly closed-ended questions, which do not promote inquiry and aligned with the requirement needed in inquiry-based classroom (National Research Council, 2000). Secondly, this study revealed that there are five types of sequences of verbal interaction after students' questions. The common sequence after students' questions is IR, where the students initiate the talk by asking questions (I), and followed by teacher responding to the questions asked (R). From this study, it was found that most of the questions asked by students were answered by teachers. This IR sequence showed that it is the common practice in the chemistry lessons observed. This may be due to teachers' negative perception on their students' ability to respond to questions asked. Teachers should be a role model in displaying a good example in moving from asking low level thinking questions (close questions) to high order thinking questions (open questions), from 'what' question to 'how' and 'what-if questions. Besides that, teachers should allocate wait-time, which refers to the time allocated for students to respond to their friend's questions. This wait-time has similar application with wait-time one, which is the duration of pause after teacher's question (Rowe, 1974). The wait-time is important as students need time to think and respond accordingly.

Hence, in order to produce better inquiry-based classroom, and student initiatedinquiry, chemistry teachers need to practice wait-time and have a positive view on students' ability to respond as one-size-fits-all model do not apply in inquiry-based classroom. Besides that, chemistry teachers should encourage and guide their students to ask open-ended questions in the classroom.

\section{REFERENCES}

Albergaria-Almeida, P. (2010). Questioning Patterns and Teaching Strategies in Secondary Education. Procedia-Social and Behavioral Science. 2(2): 751756.

Blonder, R., R. Mamlok-Naaman, and A.Hofstein. (2008). Analyzing Inquiry Questions of High School Students in A Gas Chromatography Open-Ended Laboratory Experiment. Chemistry Education Research and Practice. 9: 250-258. 
Brandon, P.R., A.K.H.Taum, D.B. Young, and F.M. Potenger III. (2008). The Development and Validation of the Inquiry Science Observation Coding Sheet. Evaluation and Program Planning. 31(3): 247-258.

Campbell, T., D. Zhang, and D. Neilson. (2011). Model Based Inquiry in the High School Physics Classroom: An Exploratory Study of Implementation and Outcomes. Journal of Science Education Technology. 20: 258-265.

Chin, C. (2002). Student-Generated Questions: Encouraging Inquisitive Minds in Learning Science. Teaching and Learning, 23(1): 59-67.

Chin, C., and J. Osborne. (2008). Students' questions: a potential resource for teaching and learning science. Studies in Science Education. 44(1): 1-39.

Curriculum Development Centre. (2005). Curriculum Specifications Chemistry Form 4. Putrajaya, Malaysia: Ministry of Education Malaysia.

Dillon, J.T. (1988). The Remedial Status of Students Questioning. Curriculum Studies. 20: 197-210.

Eggleston, J.F., M. Galton, and M. Jones. (1975). A Science Teaching Observation Schedule. London: Macmillan Education.

Flanders, N.A. (1970). Analyzing Teaching Behaviour. USA: Addison-Wesley Publishing Company.

Hinrichsen, J., and D.Jarrett. (1999). Science Inquiry for the Classroom: A Literature Review. Programme Report. Oregon: The Northway Regional Educational Laboratory.

Howes, E.N., M. Lim, and J. Campos. (2009). Journeys Into Inquiry-Based Elementary Science: Literacy Practices, Questioning and Empirical Study. Science Education. 93(2): 189-217.

Jegede, O. J., and J.O. Olajide. (1995). Wait-time, Classroom discourse, and the Influence of Sociocultural Factors in Science Teaching. Science Education. 79(3): 233-249.

Kumpulainen, K., and D. Wray (Eds.). (2002). Classroom Interaction and Social Learning: From Theory to Practice. London: Routledge Falmer.

Lemke, J.L. (1990). Talking Science: Language, Learning and Values. Westport: Ablex Publication.

Martin, R., C. Sexton, T. Franklin, J. Gerlovich, and D. McElroy, (2009). Teaching Science for All Children: An Inquiry Approach. (5th edition). Boston: Pearson.

Kim, M., A.L. Tan, and F.T. Talaue, (2013). New Vision and Challenges in Inquiry-Based Curriculum Change in Singapore. International Journal of Science Education. 35(2): 289-311.

Ministry of Education Malaysia, (2012). Preliminary Report-Executive Summary Malaysia Education Blueprint 2013 - 2025 Foreword. Retrieved August 30, 2013, from http://www4.unescobkk.org/nespap/sites/default/files/Prelimi nary-Blueprint-ExecSummary-Eng_0.pdf.

Mohammad Najib Abdul Ghafar,. (1997). Access and Success in Higher Education. Johor: University Technology Malaysia.

Mohamed Najib Abdul Ghafar and Mohammad Yusof Arshad. (1995). Peningkatan Kemahiran Saintifik Melalui Interaksi Di Bilik Daijah [Scientific Skills Enhancement through Interaction in Classroom]. Paper presented in National Teacher Education Seminar. 18-19 December 1995. Johor: University Technology Malaysia. 
Mortimer, E.F., and P.H. Scott. (2003). Meaning Making in Secondary Science Classrooms. Maidenhead: Open University Press.

National Research Council. (2000). Inquiry and the National Science Education Standards: A guide for teaching and learning. Washington D.C.: National Academy Press.

Rop, C.J. (2003). Spontaneous Inquiry Questions in High School Chemistry Classrooms: Perceptions of a Group of Motivated Learners. International Journal of Science Education. 25(1): 13-33.

Rowe, M. (1974). Wait-Time and Rewards as Instructional Variables, their Influence in Language, Logic and Fate Control: Part One-Wait Time. Journal of Research in Science Teaching. 11(2): 263-279.

Scott, P., E.F. Mortimer, and O.G. Aguiar. (2006). The Tension between Authoritative and Dialogic Discourse: A Fundamental Characteristic of Meaning Making Interactions in High School Science Lesson. Science Education. 90(4): 605-631.

Sinclair, J., and M. Coulthard. (1975). Towards an Analysis of Discourse. Oxford: Oxford University Press.

Suchman, J.R. (1966). Developing Inquiry. Chicago: Science Research Associates, Inc.

Tay, C.S., and Mohammad Yusof Arshad. (2008). Interaksi Verbal Pengajaran Dan Pembelajaran Sains Sekolah Rendah. [Verbal Interaction Teaching and Learning in Science Primary Schools]. Paper presented in National Science and Mathematics Education Seminar. 11-12 October 2008. Johor: University Technology Malaysia.

Tobin K. (1990). Research on Science Laboratory Activities: In Pursuit of Better Questions and Answers to Improve Learning. School Science and Mathematics. 90(5): 403-418.

van Zee, E.H., M. Iwasyk, A. Kurose, D. Simpson, and J. Wild. (2001). Student and Teacher Questioning during Conversations about Science. Journal of Research in Science Teaching. 38(2): 159-190.

Wells, G. (1995). Language and the Inquiry-Oriented Curriculum. Curriculum Inquiry. 25(3): 233-269.

Yehudit, D.J., and O. Herscovitz. (1999). Question Posing Capability on an Alternative Evaluation Method: Analysis of an Environmental Case Study. Journal of Research in Science Teaching. 36(4): 411-43 